DOI: https://doi.org/10.47405/mjssh.v6i4.734

\begin{tabular}{|c|c|}
\hline $\operatorname{lin}_{i=1}$ & Malaysian Journal of Social Sciences and Humanities (MJSSH) \\
\hline $\begin{array}{l}\text { Malaysian Journal of } \\
\text { Socrai scciecces and }\end{array}$ & Volume 6, Issue 4, April 2021 \\
\hline (MJ-SSH) & e-ISSN : 2504-8562 \\
\hline & $\begin{array}{l}\text { Journal home page: } \\
\text { www.msocialsciences.com }\end{array}$ \\
\hline
\end{tabular}

\title{
Sorotan Literatur Bersistematik: Pemupukan Kreativiti Matematik dalam Pendidikan Matematik
}

\author{
Ng Wen Yee ${ }^{1}$, Siti Mistima Maat ${ }^{1}$ \\ ${ }^{1}$ Fakulti Pendidikan, Universiti Kebangsaan Malaysia (UKM) \\ Correspondence: Ng Wen Yee (manyee122@gmail.com)
}

\begin{abstract}
Abstrak
Kreativiti merupakan suatu proses yang berlaku tanpa manusia sedari dan bersifat secara semula jadi dan boleh dipelajari. Kajian sistematik ini dijalankan bagi menganalisis secara kritikal dan sintesis trend pendidikan dan kaedah yang digunakan dalam kajian untuk memupuk kreativiti matematik dalam pendidikan matematik. Dua pangkalan data iaitu SCOPUS dan Education Resources Information Center (ERIC) digunakan untuk mencari artikel dari tahun 2016-2020. Kajian ini menggunakan Model PRISMA. Sebanyak 684 artikel yang menggunakan kata kunci kreativiti dan matematik telah dijumpai namun hanya 20 sahaja artikel dikenal pasti yang memenuhi syarat dan diterima dalam kajian ini. Terdapat dua persoalan kajian dalam kajian ini iaitu meninjau trend kajian kreativiti matematik dalam pendidikan dan penggunaan kaedah untuk memupuk kreativiti matematik dalam pendidikan. Dapatan analisis menunjukkan bahawa kajian-kajian pemupukan kreativiti matematik dalam pembelajaran matematik berfokus pada pelajar antara kelima-lima tahun tersebut. Manakala kaedah penggunaan pendekatan dan pengajaran guru adalah kerap digunakan sebagai sasaran untuk memupuk kreativiti matematik pelajar. Dapatan kajian menunjukkan pemupukan kreativiti matematik adalah membawa kesan dan impak yang positif dalam pendidikan. Walau bagaimanapun, jumlah kajian yang berfokus kepada pemupukan kreativiti matematik dalam pendidikan Malaysia masih dikirakan sedikit. Justeru diharapkan agar kajian lanjutan dalam bidang ini boleh diperbanyakkan lagi dalam konteks pendidikan matematik pada masa akan datang.
\end{abstract}

Kata kunci: kreativiti, kreativiti matematik, pendidikan, matematik, sorotan literatur

\section{Systematic Literature Highlights: Fostering Mathematical Creativity in Mathematics Education}

\begin{abstract}
Creativity is a process that occurs without humans being aware and is natural and learnable. This systematic study was conducted aimed to critically analyze and synthesize educational trends and methods used in the studies to foster mathematical creativity in mathematics education. There are two databases which namely SCOPUS and Education Resources Information Center (ERIC) were used to search for articles from 2016-2020. This study uses the PRISMA Model. A total of 684 articles using the keywords creativity and mathematics were found but only 20 articles were identified that qualified and accepted in this study. There are two research questions in this study which to review the research trends of mathematical creativity in education and the use of methods to foster mathematical creativity in education. The findings of the analysis indicate that the studies of fostering mathematical creativity in mathematics learning focused on students within the five years. While the method of using the approach and teaching
\end{abstract}


of teachers is often used as a target to foster students' mathematical creativity. The findings show that fostering mathematical creativity has a positive effect and impact in education. However, the number of studies focusing on fostering mathematical creativity in Malaysian education is lack . Therefore, this study aimed to expected that more research in this field can be multiplied further in the context of mathematics education in the future.

Keywords: creativity, mathematical creativity, mathematic, education, literature review

\section{Pengenalan}

Pendidikan merupakan salah satu tonggak utama yang sejajar dalam proses pembangunan aspirasi negara. Reformasi pendidikan sering berlaku atas kesan dan cabaran daripada perubahan secara global ini (UNESCO, 2015). Oleh itu, sistem pendidikan negara sering mengalami perubahan supaya dapat mengejar arus perubahan tersebut dengan tujuan memenuhi keperluan perkembangan perubahan dalam bidang pendidikan. Contohnya, pihak pendidikan kerajaan Malaysia telah memperkenalkan Pelan Pembangunan Pendidikan Malaysia 2013-2025 untuk menggubal pendidikan Malaysia yang sedia ada supaya sejajar dengan perubahan dunia tanpa tercicir di belakang. Perubahan pendidikan digubal dengan tujuannya meningkatkan taraf pendidikan rakyat, membekalkan ilmu pendidikan yang terbaru, meningkatkan daya bersaing rakyat serta melahirkan insan yang berilmu dan berkemahiran tinggi untuk mengharungi arus globalisasi yang kian mencabar.

Perubahan ini telah meningkatkan kepentingan kemahiran kreativiti. Perkara ini dapat diperlihatkan menerusi Pelan Pembangunan Pendidikan Malaysia (PPPM) 2013-2025, dalam bahagian aspirasi murid, murid dihasratkan untuk menguasai tiga kemahiran kognitif yang penting, iaitu pemikiran kreatif dan inovatif, penyelesaian masalah dan penaakulan serta keupayaan belajar (Kementerian Pendidikan Malaysia, 2013). Hal ini adalah kerana perubahan reformasi ini akan membantu menghasilkan sumber tenaga yang berkeupayaan serta berkemahiran tinggi dari segi kreatif dan inovatif selain daripada intelek dalam kalangan rakyat. Tujuan ini dapat melestarikan kemajuan dan membangunkan daya tahan masyarakat dan negara semasa mengharungi arus cabaran globalisasi dunia. Oleh itu, perubahan ini perlu mulai dilaksanakan menerusi dunia pendidikan di mana bakal sumber tenaga negara dipupuk dari kecil lagi.

Tujuan utama kajian ini dijalankan adalah untuk mengkaji trend kajian kreativiti matematik dalam pendidikan melalui tinjauan dengan kajian-kajian empirikal yang telah dipilih. Trend kajian diteliti dengan tahun penerbitan, negara, reka bentuk kajian, sampel dan instrumen kajian. Justeru itu, persoalanpersoalan dalam sorotan literatur bersistematik adalah seperti berikut:

i. Apakah trend kajian kreativiti matematik dalam pendidikan?

ii. Apakah kaedah pemupukan kreativiti matematik dalam pendidikan yang dijalankan dalam penyelidikan empirikal?

\section{Sorotan Literatur}

Kreativiti adalah satu pemikiran yang penting untuk menyelesaikan masalah (De Bono, 2015) kerana kreativiti berperanan untuk meningkatkan kemampuan individu untuk berfikir secara kritis, mengenal pasti dan menyelesaikan masalah dan berkomunikasi dengan berkesan (Wood et al., 2017). Menurut Chua (2011) kreativiti adalah suatu konsep yang abstrak, oleh yang demikian, pelbagai definisi telah dikemukakan oleh para penyelidik dan para cendekiawan. Menurut perspektif psikologi, kreativiti didefinisikan sebagai suatu keupayaan untuk menghasilkan sesuatu idea atau produk yang baru dan bernilai.

Pemikiran kreativiti menggalakkan individu mencari cara penyelesaian melalui perspektif yang baru, berbeza dan inovatif supaya mengatasi cabaran dan mencapai matlamat (Cropley, 2015). Oleh itu, pemikiran kreatif penting dalam kehidupan kerana kreativiti dapat digunakan untuk menyelesaikan 
masalah. Selain itu, kreativiti dapat meningkatkan keupayaan untuk mengatasi cabaran dan juga dapat bersemangat semula.

Manakala kreativiti matematik telah dilihat sebagai proses yang menghasilkan penyelesaian yang tidak seperti umum ataupun hanya sepadan terhadap sesuatu masalah tertentu sahaja. Ia juga boleh dikatakan bahawa idea atau kemungkinan baru yang dihasilkan dari perspektif pandangan serta daya imaginasi yang berbeza (Sriraman, 2005). Tambahan pula, Leikin (2007) pula menyatakan bahawa seseorang akan mempertimbangkan idea-idea matematik dari sudut berbeza-beza semasa berusaha mencari kepelbagaian cara penyelesaian, maka dia akan membentuk pengetahuan kreativiti yang mendalam dalam matematik. Terdapat kajian juga menunjukkan bahawa kreativiti matematik adalah prasyarat untuk mengembangkan kebolehan matematik (Kattou et al., 2013).

Selain itu, juga terdapat kajian lain juga menunjukkan bahawa semakin tinggi daya kreatif seseorang kanak-kanak dalam matematik, maka semakin tahap prestasinya dalam matematik (Bahar \& Maker, 2011; Kattou et al., 2013; Leikin, 2007). Keadaan ini juga disokong oleh Van Harpen dan Sriraman (2013) bahawa kreativiti matematik adalah salah satu aspek cara penyelesaian yang penting dalam masalah matematik.

\section{Metod Kajian}

Kaedah sorotan literatur bersistematik telah digunakan dalam kajian ini untuk menganalisis trend kajian kreativiti matematik dalam pendidikan serta kaedah pemupukan kreativiti matematik dalam pendidikan yang dijalankan dalam penyelidikan empirikal. Pada masa yang sama, analisis pengendalian dan pelaporan dapatan artikel telah telah dijalankan dengan merujuk kepada garis paduan model PRISMA (Systematic Reviews and Meta-Analyses). Rujukan terhadap Model PRISMA telah dipilih sebagai panduan kerana dapat membantu para penyelidik mengendalikan maklumat yang diperlukan demi langkah ke langkah dan pada masa yang sama dapat mengekalkan kualiti sorotan yang ingin dihasilkan (Shaffril et al., 2019).

Proses penghasilan sorotan literatur bersistematik ini telah melalui empat peringkat pemilihan artikel iaitu pengenalpastian (identification), penapisan (screening), kelayakan (eligibility) dan termasuk (inclusion) seperti yang dinyatakan dalam kajian Gilath dan Karantzas (2019). Pada permulaan, pencarian telah dijalankan untuk mencari artikel yang berkaitan dengan pemupukan kreativiti matematik dalam pendidikan matematik. Pencarian artikel dijalankan berdasarkan artikel yang berpusatkan tajuk kreativiti dalam matematik. Pencarian dijalankan melalui dua pangkalan data elektronik iaitu Scopus dan Education Resources Information Center (ERIC). Pencarian di pangkalan data telah menggunakan beberapa kata istilah carian berikut gabungan dalam Bahasa Inggeris mengenai "creativity", " mathematic", "creativiti thinking", dan "mathematical creativity". Selain kata istilah tersebut, penggunaan istilah alternatif dalam Bahasa Melayu seperti "kreativiti ”, "matematik" , "inovasi" dan "pemikiran kreativiti”.

Terdapat beberapa kriteria pencarian penulisan artikel telah ditetapkan sebelum memulakan proses pencarian. Pertamanya, sumber artikel dihadkan dalam tempoh lima tahun penerbitan terkini iaitu dari Januari 2016 hingga 2020. Tujuannya untuk mendapatkan maklumat yang terkini tentang perkembangan kreativiti matematik dalam dunia pendidikan. Artikel yang dipilih hanya mempunyai data empirikal sahaja. Selain itu, kriteria pemilihan artikel terpilih juga termasuk hanya melibatkan artikel akses terbuka. Tujuan ini untuk memudahkan proses perolehan dan muat turun artikel. Tambahan pula, pencarian ini berfokus kreativiti kepada pendidikan matematik. Tinjauan awalan dijalankan dengan berdasarkan tajuk artikel, abstrak dan kata kunci. Teks penuh dicari dan dibaca untuk artikel yang memenuhi kriteria kelayakan berdasarkan tajuk dan abstrak dan menentukan sama ada artikel ini akan dikekalkan atau dikecualikan dalam pencarian terakhir atau tidak. Menurut Haas dan Springer (1998), tujuan melakukan penyelidikan yang sistematik adalah untuk meningkatkan jumlah penemuan sehingga hasil carian berkaitan didapatkan. Manakala bagi penolakan kriteria sumber artikel termasuk penulisan penyelidikan yang lain seperti buku, laporan atau prosiding yang tidak diterbitkan, tesis dan disertasi tidak termasuk dalam pemilihan ini. Penulisan sumber-sumber ilmiah ini tidak dipilih kerana objektif dan kredibiliti mereka yang harus diambil kira sebagai mereka tidak melalui proses tinjauan rakan sebaya 
(Liyanagunawardena et al., 2013). Di samping itu, sumber penulisan kajian juga hanya memilih artikel yang ditulis dalam Bahasa Melayu dan Inggeris sahaja.

Hasil pencarian dari pangkalan data elektronik Scopus dan Education Resources Information Center (ERIC) telah mendapatkan sebanyak 389 dan 295 buah artikel masing-masing dengan istilah carian gabungan dalam Bahasa Inggeris mengenai "creativity", "mathematic". Proses penyaringan telah diteruskan dengan menolak artikel yang tidak memenuhi kriteria penulisan yang diingini. Pada akhirnya, sebanyak 20 buah artikel yang berkaitan dengan kreativiti dalam matematik telah dipilih dan diperlukan untuk menghasilkan sorotan literatur sistematik ini.

\section{Rajah 1 : Model PRISMA}

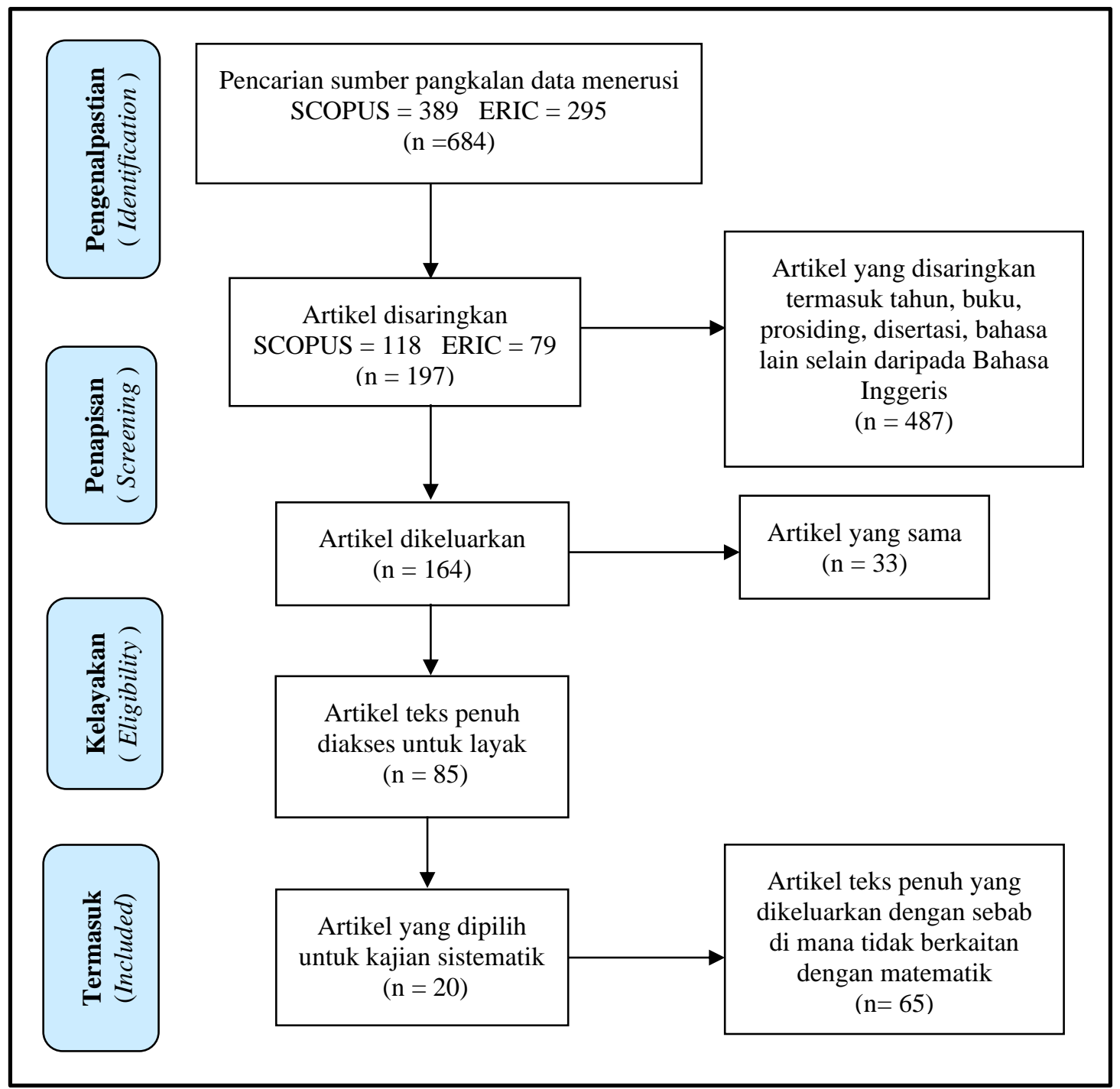

\section{Hasil Kajian}

Bagi menjawab persoalan kajian pertama, kaedah analisis deskriptif akan digunakan untuk menganalisis kandungan artikel yang telah didapatkan. Perkembangan trend kajian kreativiti matematik akan dianalisis melalui 20 buah artikel yang ditemui dalam kajian ini. Analisis akan dijalankan berkaitan dengan tahun penerbitan, negara, reka bentuk kajian, sampel dan instrumen kajian. 


\section{Tahun Penerbitan}

Jadual 1 menunjukkan tahun penerbitan antara tahun 2016 hingga 2020. Trend bagi pemupukan kreativiti matematik dalam pendidikan matematik mengikut tahun adalah tidak seimbang dengan kajian paling banyak dilakukan pada tahun 2020 iaitu sebanyak 9 kajian. Diikuti dengan pada tahun 2019 dengan sebanyak 4 kajian. Manakala sebanyak dua kajian pada tahun 2018 dan sebanyak 5 kajian diterbitkan pada tahun 2016 Tahun 2017 merupakan tahun yang tiada penerbitan berlaku. Dapatan menunjukkan bahawa kajian yang banyak mengenai khazanah pengetahuan adalah pada tahun 2020. Ini menunjukkan bahawa ramai pengkaji mula berminat untuk membuat kajian tentang pemupukan kreativiti matematik dalam pendidikan matematik.

Jadual 1: Tahun penerbitan kajian

\begin{tabular}{|c|c|c|}
\hline Tahun Penerbitan & Bilangan & Penulis \\
\hline 2016 & 5 & $\begin{array}{l}\text { Akgul \& Kahveci; Bishara; Chesimet, Githua \& } \\
\text { Ng'en ; Fatah, Suryadi \& Sabandar; Lince }\end{array}$ \\
\hline 2017 & 0 & - \\
\hline 2018 & 2 & Aziza dan Nuha, Waluya \& Junaedi \\
\hline 2019 & 4 & $\begin{array}{l}\text { Catarino et al.; Schindler \& Lilienthal; Velikova } \\
\& \text { Petkova; Wahyudi, Waluya \& Isnaro }\end{array}$ \\
\hline 2020 & 9 & $\begin{array}{l}\text { Barraza-García, Romo-Vázquez. \& Roa-Fuentes; } \\
\text { Jebur; Khalid et.al; García Lázaro. Abia \& Calvo; } \\
\text { Regier \& Savic; Stolte, García, Van Luit, Oranje, } \\
\text { \& Kroesbergen; Tong et.al.; Tubb, Marrone, } \\
\text { Patston \& Kaufman; Yaniawati et al. }\end{array}$ \\
\hline
\end{tabular}

\section{Negara Mengikut Penerbitan}

Jadual 2 menunjukkan sebanyak 14 buah negara yang terlibat dalam kajian yang telah dijalankan. Negara yang paling banyak menjalankan kajian terkini mengenai kreativiti matematik ialah negara Indonesia sebanyak 5 kajian manakala negara lain hanya 1 kajian sahaja.

Jadual 2: Negara mengikut penerbitan

\begin{tabular}{lcl}
\hline \multicolumn{1}{c}{ Negara } & Bilangan & \multicolumn{1}{c}{ Penulis } \\
\hline Amerika Syarikat & 1 & Regier \& Savic (2020) \\
Australia & 1 & Tubb, Marrone, Patston \& Kaufman (2020) \\
Bulgaria & 1 & Velikova \& Petkova (2019) \\
Indonesia & 5 & $\begin{array}{l}\text { Yaniawati, et.al. (2020) } \\
\text { Wahyudi, Waluya \& Isnaro(2019) } \\
\end{array}$ \\
& & Nuha, Waluya, \& Junaedi (2018) \\
& & Fatah, Suryadi \& Sabandar ( 2016) \\
& & Lince (2016) \\
Iraq & 1 & Jebur (2020) \\
Israel & 1 & Bishara (2016) \\
Kenya & 1 & Chesimet, Githua \& Ng'eno (2016) \\
Malaysia & 1 & Khalid et.al (2020) \\
Mexico & 1 & Barraza-García, Romo-Vázquez \& Roa-Fuentes \\
& & (2020) \\
Netherlands & 1 & Stolte, García, Van Luit, Oranje \& Kroesbergen \\
& & (2020) \\
Portugal & 1 & Catarino et.al. (2019) \\
Spain & 1 & García Lázaro, Abia, \& Calvo (2020) \\
Sweden & 1 & Schindler \& Lilienthal ( 2019) \\
\hline
\end{tabular}


DOI: https://doi.org/10.47405/mjssh.v6i4.734

\begin{tabular}{lll}
\hline Turkey & 1 & Akgul \& Kahveci (2016) \\
United Kingdom & 1 & Aziza (2018) \\
Vietnam & 1 & Tong et.al. (2020) \\
\hline
\end{tabular}

\section{Sampel Kajian}

Jadual 3 di bawah menunjukkan trend dari segi sampel kajian pula menunjukkan tiada keseimbangan antara pelajar dan guru. Sampel kajian adalah berfokus pada pelajar. Antara 20 buah artikel, sebanyak 18 buah artikel adalah berfokus pada sampel pelajar. Manakala hanya satu buah sampel kajian yang masingmasing berfokus kepada guru serta pelajar dan guru. Ini menunjukkan bahawa pemupukan kreativiti matematik semakin dititikberatkan oleh para pendidik dalam dunia pendidikan matematik.

Jadual 3: Sampel Kajian

\begin{tabular}{lcl}
\hline \multicolumn{1}{c}{ Sampel kajian } & Bilangan & \multicolumn{1}{c}{ Penulis } \\
\hline Murid & 18 & Akgul \& Kahveci (2016); Barraza-García, Romo- \\
& Vázquez \& Roa-Fuentes (2020); Bishara (2016); \\
& Catarino et.al. (2019); Chesimet, Githua \& Ng'eno \\
& (2016); Fatah, Suryadi \& Sabandar ( 2016); \\
& Jebur (2020); Khalid et. al (2020); García Lázaro, \\
& Abia, \& Calvo (2020); Lince (2016); Nuha, \\
& Waluya, \& Junaedi (2018); Regier \& Savic \\
& (2020); Schindler \& Lilienthal (2019); Stolte, \\
& García, Van Luit, Oranje \& Kroesbergen (2020); \\
& Tong et.al. (2020); Tubb, Marrone, Patston \& \\
& Kaufman (2020); Wahyudi, Waluya \& Isnaro \\
& (2019); Yaniawati, et.al. (2020) \\
Guru & Velikova \& Petkova (2019) \\
Murid dan guru & Aziza (2018) \\
\hline
\end{tabular}

\section{Reka bentuk Kajian}

Berdasarkan Jadual 4, didapati penyelidikan kuantitatif adalah paling banyak digunakan dalam kajian yang memupuk kreativiti matematik, iaitu sebanyak sembilan kajian. Dalam penyelidikan kuantitatif berdasarkan kajian-kajian empirikal, kebanyakan kajian dijalankan dengan kaedah eksperimental dan kuasi eksperimental bagi mengumpulkan data, dan pemilihan saiz sampel adalah besar. Selain itu, terdapat tujuh kajian adalah berbentuk penyelidikan kualitatif. Manakala terdapat sebanyak empat buah kajian yang berbentuk penyelidikan gabungan di mana pengkaji menggunakan kedua-dua penyelidikan kuantitatif dan kualitatif untuk memastikan maklumat yang diperoleh adalah munasabah dan bermanfaat.

Jadual 4: Reka Bentuk Kajian

\begin{tabular}{lcl}
\hline Reka bentuk kajian & Bilangan & \multicolumn{1}{c}{ Penulis } \\
\hline Kuantitatif & 9 & Bishara (2016) \\
& Catarino et.al. (2019) \\
& Chesimet, Githua \& Ng'eno (2016) \\
& Fatah, Suryadi \& Sabandar (2016) \\
& Jebur (2020) \\
& Lince (2016) \\
& Stolte, García, Van Luit; Oranje \& Kroesbergen \\
& (2020) \\
& Tong et.al. (2020) \\
& \\
& Tubb, Marrone, Patston \& Kaufman (2020) \\
Kualitatif & Akgul \& Kahveci (2016) \\
& & Aziza (2018) \\
\hline
\end{tabular}




\begin{tabular}{ll}
\hline & Barraza-García, Romo-Vázquez \& Roa-Fuentes \\
& (2020) \\
& García Lázaro, Abia \& Calvo (2020) \\
& Schindler \& Lilienthal (2019) \\
& Velikova \& Petkova (2019) \\
& Wahyudi, Waluya \& Isnaro (2019) \\
Gabungan & Khalid et al. (2020) \\
& Nuha, Waluya \& Junaedi (2018) \\
& Regier \& Savic (2020) \\
& Yaniawati et.al. (2020) \\
\hline
\end{tabular}

\section{Instrumen Kajian}

Instrumen yang telah digunakan dalam kajian telah ditunjukkan Jadual 5. Berdasarkan analisis mendapati bahawa instrumen ujian adalahlah paling banyak digunakan dalam kajian. Jenis ujian yang digunakan dalam kajian ialah ujian pra dan ujian pos, ujian kreativiti dan ujian skala kreativiti. Instrumen kedua yang kerap digunakan oleh para penyelidik ialah temu bual dengan diikuti soal selidik semasa menjalankan kajian. Selain itu, instrumen lain-lain seperti analisis nota lapangan, rancangan pengajaran guru serta penilaian pelajar juga antara instrumen kajian yang digunakan dalam kajian kreativiti matematik. Hal ini demikian kerana penggunaan kajian kualitatif sebagai kaedah mengumpul data seperti temu bual, pemerhatian dan analisis dokumen.

Jadual 5: Instrumen Kajian

\begin{tabular}{|c|c|c|c|c|c|}
\hline Kajian & Ujian & Soal Selidik & Temu Bual & Pemerhatian & Lain-lain \\
\hline Regier \& Savic (2020) & & $\mathrm{x}$ & $\mathrm{x}$ & $\mathrm{x}$ & \\
\hline Barraza-García, Romo- & & & & $\mathrm{x}$ & $\mathrm{x}$ \\
\hline \multicolumn{6}{|l|}{ Vázquez \& Roa- } \\
\hline \multicolumn{6}{|l|}{ Fuentes( 2020) } \\
\hline Khalid, et.al ( 2020) & $\mathrm{x}$ & & & $\mathrm{x}$ & \\
\hline Tubb, Marrone, Patston & $\mathrm{x}$ & & & & \\
\hline \multicolumn{6}{|l|}{ \& Kaufman (2020) } \\
\hline Catarino et.al. (2019) & $\mathrm{x}$ & & & & \\
\hline García Lázaro,.Abia, \& & & $\mathrm{x}$ & $\mathrm{x}$ & & \\
\hline \multicolumn{6}{|l|}{ Calvo (2020) } \\
\hline Schindler \& Lilienthal & & & $\mathrm{x}$ & & \\
\hline \multicolumn{6}{|l|}{ (2019) } \\
\hline Stolte, García, Van Luit, & $\mathrm{x}$ & & & & \\
\hline \multicolumn{6}{|l|}{ Oranje \& Kroesbergen } \\
\hline \multicolumn{6}{|l|}{ (2020) } \\
\hline Bishara (2016) & & $\mathrm{x}$ & & & \\
\hline Wahyudi, Waluya \& & $\mathrm{x}$ & & $\mathrm{x}$ & & \\
\hline Isnaro (2019) & & & & & \\
\hline
\end{tabular}




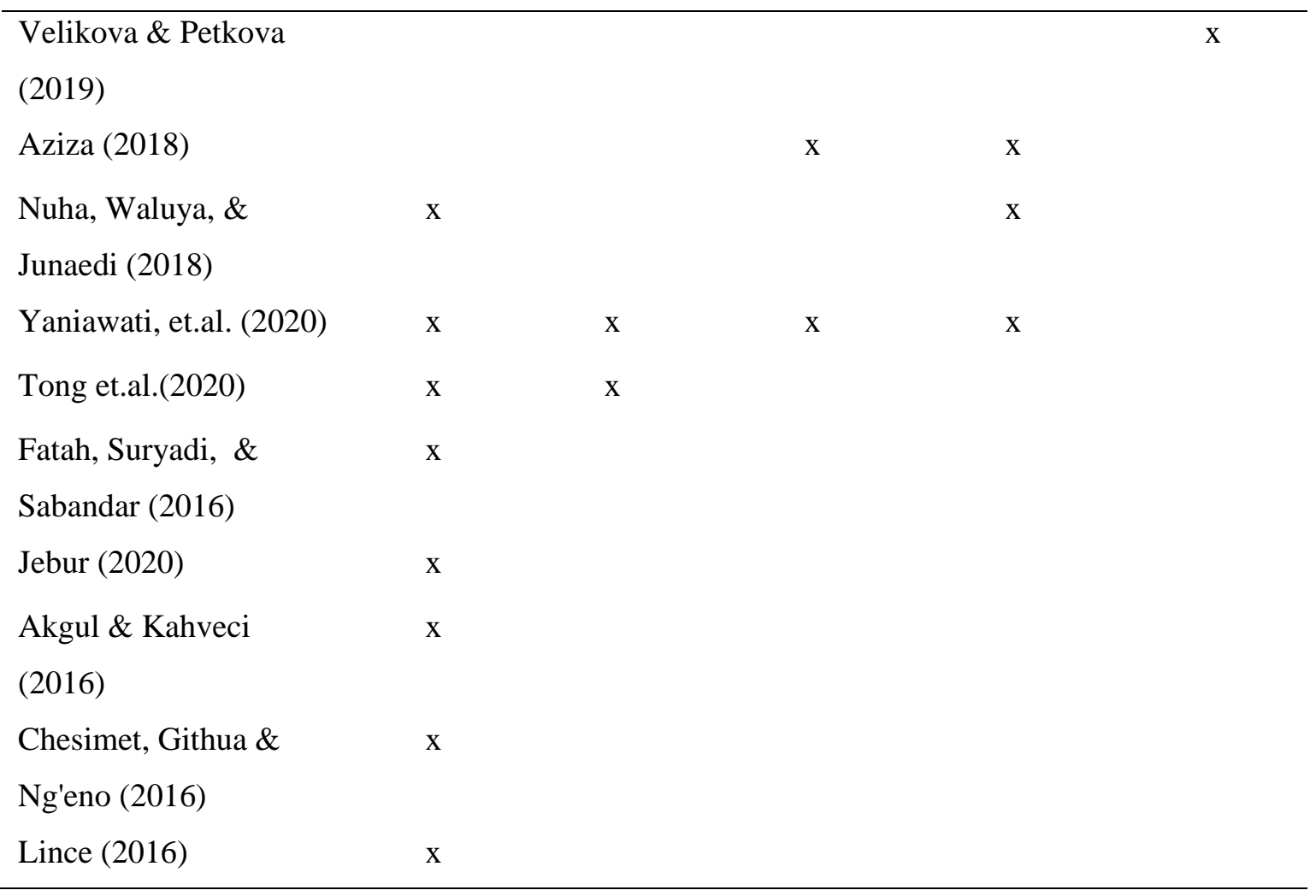

Dapatan kajian bagi menjawab persoalan kajian kedua akan ditunjukkan melalui jadual 6 di bawah. iaitu analisis penggunaan kaedah oleh para penyelidik untuk memupuk kreativiti matematik dalam pendidikan matematik.

\section{Analisis kaedah pemupukan kreativiti matematik yang digunakan}

Untuk menjawab persoalan kajian kedua ini, analisis penggunaan kaedah yang digunakan oleh para penyelidik dalam kajian mereka untuk memupuk atau meningkatkan kreativiti matematik. Setelah dianalisis, terdapat tiga jenis kaedah yang digunakan iaitu berjenis model, teori pembelajaran dan pendekatan dan pengajaran. Antaranya, terdapat tiga buah kajian yang menggunakan kaedah model (Barraza-García, Romo-Vázquez \& Roa-Fuentes, 2020; Jebur, 2020; Lince, 2016). Manakala modelmodel yang digunakan ialah Theoretical Model, Alan Hoffer's model dan Models Numbered Heads Together. Terdapat tiga buah kajian yang menggunakan kaedah teori dalam kajian mereka (Regier \& Savic, 2020; Catarino et al., 2019; Wahyudi, Waluya \& Isnaro, 2019). Teori-teori tersebut adalah teori psikologi pembelajaran yang terkenal dalam bidang pendidikan, iaitu Teori Efikasi Kendiri Bandura, Teori Koperatif dan Teori Skema (Teori Perkembangan Kognitif Piaget). Yang selebihnya ialah penggunaan kaedah pendekatan dan pengajaran guru matematik. Pendekatan dan pengajaran seperti digital dan teknologi, penyelesaian dan pernyataan masalah, pengajaran Inequaliti dan fungsi dan pengajaran guru serta penggunaan skala kreativiti. Dapatan hasil analisis mendapati bahawa pemupukan kreativiti matematik dalam pendidikan dengan kaedah yang berlainan adalah didapati berkesan dan membawa peningkatan serta impak yang positif.

Jadual 6: Analisis kaedah pemupukan kreativiti matematik yang digunakan

\begin{tabular}{lll}
\hline & Jenis Kaedah & \multicolumn{1}{c}{ Penulis (Tahun) } \\
\hline Model, $\mathrm{n}=3$ & Theoretical Model & $\begin{array}{l}\text { Barraza-García, Romo-Vázquez \& } \\
\text { Roa-Fuentes( 2020) } \\
\text { Jebur (2020) }\end{array}$ \\
& $\begin{array}{l}\text { Alan Hoffer's model } \\
\text { Models Numbered Heads } \\
\text { Together }\end{array}$ & Lince (2016) \\
Teori, $\mathrm{n}=3$ & Teori Efikasi Kendiri & Regier \& Savic (2020) \\
\hline
\end{tabular}


DOI: https://doi.org/10.47405/mjssh.v6i4.734

\begin{tabular}{|c|c|c|}
\hline \multirow{8}{*}{$\begin{array}{l}\text { Pendekatan \& } \\
\text { pengajaran, } \\
\mathrm{n}=14\end{array}$} & Teori Koperatif & Catarino et.al. (2019) \\
\hline & Teori Skema & Wahyudi, Waluya \& Isnaro (2019) \\
\hline & Digital dan teknologi & $\begin{array}{l}\text { Tubb, Marrone, } \quad \text { Patston \& } \\
\text { Kaufman (2020); Schindler \& } \\
\text { Lilienthal (2019); ; Velikova } \quad \text { \& } \\
\text { Petkova (2019) }\end{array}$ \\
\hline & $\begin{array}{l}\text { Penyelesaian dan pernyataan } \\
\text { masalah }\end{array}$ & $\begin{array}{l}\text { Khalid, et.al ( 2020) ; Nuha, } \\
\text { Waluya, \& Junaedi (2018); Bishara } \\
\text { (2016) }\end{array}$ \\
\hline & $\begin{array}{l}\text { Pengajaran Inequaliti dan } \\
\text { fungsi }\end{array}$ & $\begin{array}{l}\text { García Lázaro,.Abia, \& Calvo } \\
\text { (2020) ; Stolte, García, Van Luit, } \\
\text { Oranje \& Kroesbergen (2020) ; } \\
\text { Tong et.al.(2020) }\end{array}$ \\
\hline & Pengajaran guru & $\begin{array}{l}\text { Aziza (2018) ; Yaniawati, et.al. } \\
\text { (2020) ; Fatah, Suryadi, \& } \\
\text { Sabandar (2016) ; Chesimet, Githua } \\
\text { \& Ng'eno (2016) }\end{array}$ \\
\hline & Skala Kreativiti & Akgul \& Kahveci (2016) \\
\hline & Theoretical Model & $\begin{array}{l}\text { Barraza-García, Romo-Vázquez \& } \\
\text { Roa-Fuentes( 2020) }\end{array}$ \\
\hline
\end{tabular}

\section{Perbincangan Kajian}

Kajian-kajian yang dianalisis telah menunjukkan bahawa kreativiti matematik sememangnya membawa impak yang positif dalam pembelajaran. Trend perkembangan kreativiti matematik dapat diperlihatkan melalui analisis dapatan kajian. Perkembangan kreativiti matematik dalam pendidikan semakin dititikberatkan dengan sejajar perkembangan perubahan dunia terutamanya di negara benua Asia. Tambahan pula, gaya pengajaran guru dalam pengajaran dan pemudahcaraan telah mula berubah dengan menerapkan kepelbagaian pengajaran dan pendekatan untuk memupuk kreativiti matematik dalam kalangan murid. Hal ini dapat diperlihatkan melalui analisis dapatan kajian bahawa majoriti kajian telah menunjukkan bahawa guru memperbanyakkan gaya pengajaran dalam pemupukan matematik. Ini adalah disokong dalam kajian Betty dan Jamil (2017) bahawa pengetahuan guru akan menentukan keberkesanan pengajaran dan pemudahcaraan. Aktiviti pembelajaran yang dipilih oleh guru yang bersesuaian akan menyumbang dalam peningkatan pencapaian, keupayaan serta penguasaan pelajar dalam sesuatu pembelajaran. Dengan itu, boleh dikatakan bahawa penggunaan kreativti matematik dapat membantu murid lebih berfikir kritis, kreatif, menganalisis dan menggunakan strategi untuk menyelesaikan masalah terutamanya dalam pembelajaran matematik. Hal ini adalah kerana pelajar akan mula berminat dan memberi fokus terhadap pembelajaran matematik. Oleh itu, kreativiti matematik memainkan peranan yang penting dalam pembelajaran.

\section{Kesimpulan}

Pengajaran kreativiti matematik semakin dititikberatkan bidang pendidikan terutamanya dalam era perubahan transformasi sistem pendidikan ini. Dalam melahirkan murid yang mempunyai kemahiran bersesuaian perkembangan dunia, corak pengajaran dalam bilik darjah perlu bersesuaian dengan perkembangan generasi sekarang. Murid perlu didedahkan dengan cara pengajaran yang dapat menjana pemikiran secara kreatif dan kritis. Penggunaan kaedah pemupukan kreativiti matematik perlu bersesuaian agar penggunaannya dapat memberikan kesan yang bermakna kepada pelajar. Penguasaan pengajaran kreativiti yang berkesan memainkan peranan penting dalam melahirkan warganegara yang cemerlang, gemilang dan terbilang yang dapat menyumbang ke arah realisasi aspirasi negara. Justeru, para pendidik guru seharusnya didedahkan pengajaran kreativiti matematik yang merangkumi pelbagai domain dan justeru mengaplikasikan dalam pengajaran dan pemudahcaraan mereka pada masa kelak. Diharapkan kajian-kajian ini dicadangkan dilanjutkan supaya dapat membawa hasil kajian yang amat membantu dalam pendidikan matematik khususnya dalam bidang pendidikan matematik di Malaysia. 


\section{Rujukan}

Akgul, S., \& Kahveci, N. G. (2016). A study on the development of a mathematics creativity scale. Eurasian Journal of Educational Research, 16(62), 57-62. https://doi.org/10.14689/ejer.2016.62.5

Aziza, M. (2018). An analysis of a teacher's questioning related to students' responses and mathematical creativity in an elementary school in the UK. International Electronic Journal of Elementary Education, 10(4), 475-487. https:// doi.org/ 10.26822/iejee.2018438138

Bahar, A. K., \& Maker, C. J. (2011). Exploring the relationship between mathematical creativity and mathematical achievement. Asia-Pacific Journal of Gifted and Talented Education, 3(1), 33-48.

Betty Fredolin \& Jamil Ahmad. (2017). Kesan pembelajaran kolaboratif terhadap penguasaan konsep sains pelajar tingkatan satu. Seminar Kebangsaan Sains Dan Psikologi Dalam Pendidikan, 1-8.

Barraza-García, Z. M., Romo-Vázquez, A., \& Roa-Fuentes, S. (2020). A theoretical model for the development of mathematical talent through mathematical creativity. Education Sciences, 10(4), 118. https:// doi.org/10.3390/educsci10040118

Bishara, S. (2016). Creativity in unique problem-solving in mathematics and its influence on motivation for learning. Cogent Education, 3(1), 1202604.

Catarino, P., Vasco, P., Lopes, J., Silva, H., \& Morais, E. (2019). Cooperative learning on promoting creative thinking and mathematical creativity in higher education. REICE: Revista Iberoamericana sobre Calidad, Eficacia y Cambio en Educación, 17(3), 5-22. https://doi.org/10.15366/reice2019.17.3.001

Chesimet, M. C., Githua, B. N., \& Ng'eno, J. K. (2016). Effects of Experiential Learning Approach on Students' Mathematical Creativity among Secondary School Students of Kericho East Sub-County, Kenya. Journal of Education and Practice, 7(23), 51-57. Retrieved from https://eric.ed.gov/?id=EJ1112801

Chua, Y. P. (2011). Pengukuran semasa kreativiti. Isu dan cabaran. Dalam Azrina, S. (ed). Islam, Kreativiti dan Inovasi. Institut Kefahaman Islam Malaysia.

Cropley, D. H. (2015). Promoting creativity and innovation in engineering education. Psychology of Aesthetics, Creativity, and the Arts, 9(2), 161. https://doi.org/10.1037/aca0000008

De Bono, E. (2015). Serious creativity: How to be creative under pressure and turn ideas into action. Random House.

Fatah, A., Suryadi, D., \& Sabandar, J. (2016). Open-Ended Approach: An Effort in Cultivating Students' Mathematical Creative Thinking Ability and Self-Esteem in Mathematics. Journal on Mathematics Education, 7(1), 11-20. https://eric.ed.gov/?id=EJ1096314

García Lázaro, D., Garrido Abia, R., \& Marcos Calvo, M. Ángel. (2020). The use of stories and creativity for the training of future teachers of children in the teaching and learning of mathematics. Interuniversity Electronic Journal of Teacher Formation, 23(1). https://doi.org/10.6018/reifop.370071

Gillath, O., \& Karantzas, G. (2019). Attachment security priming: A systematic review. Current opinion in psychology, 25, 86-95. https://doi.org/10.1016/j.copsyc.2018.03.001

Haas, P. J., Springer,J. F. (1988). Applied policy research: Concepts and cases. Routledge.

Jebur, A. (2020) Identification of instructional learning design by Alan Hoffer's model and its effect on students' creative thinking in mathematics. Journal for the Education of Gifted Young Scientists, 8(2), 783-793. https://doi.org/10.17478/jegys.703766

Kattou, M., Kontoyianni, K., Pitta-Pantazi, D., \& Christou , C. (2013). Connecting mathematical creativity to mathematical ability. ZDM Mathematical Education, 45, 167-181. https://doi.org/10.1007/s11858-012-0467-1

Kementerian Pendidikan Malaysia. (2013). Dokumen Standard Kurikulum Pentaksiran (DSKP) Matematik Tahun 3. Putrajaya: Kementerian Pendidikan Malaysia. https://www.moe.gov.my/muat-turun/penerbitan-dan-jurnal/dskp-kssr/1278-dskp-kssr-matematiktahun-3/file

Khalid, M., Saad, S., Hamid, S. R. A., Abdullah, M. R., Ibrahim, H., \& Shahrill, M. (2020). Enhancing creativity and problem solving skills through creative problem solving in teaching mathematics. Creativity Studies, 13(2), 270-291. https://doi.org/10.3846/cs.2020.11027 
Leikin, R. (2009). Bridging research and theory in mathematics education with research and theory in creativity and giftedness. In Creativity in mathematics and the education of gifted students (pp. 383-411). Brill Sense. https://doi.org/10.1163/9789087909352_024

Lince, R. (2016). Creative thinking ability to increase student mathematical of junior high school by applying models numbered heads together. Journal of Education and Practice, 7(6), 206-212. https://eric.ed.gov/?id=EJ1092494

Liyanagunawardena, T. R., Adams, A. A., \& Williams, S. A. (2013). MOOCs: A systematic study of the published literature 2008-2012. International Review of Research in Open and Distributed Learning, 14(3), 202-227.

Nuha, M. A., Waluya, S. B., \& Junaedi, I. (2018). Mathematical Creative Process Wallas Model in Students Problem Posing with Lesson Study Approach. International Journal of Instruction, 11(2), 527-538. https:// doi.org/10.12973/iji.2018.11236a

Regier, P., \& Savic, M. (2020). How teaching to foster mathematical creativity may impact student selfefficacy for proving. The Journal of Mathematical Behavior, 57, 100720.

Schindler, M., \& Lilienthal, A. J. (2020). Students' Creative Process in Mathematics: Insights from EyeTracking-Stimulated Recall Interview on Students' Work on Multiple Solution Tasks. International Journal of Science and Mathematics Education, 18(8), 1565-1586. https://doi.org/10.1007/s10763019-10033-0

Shaffril, H. A. M., Samah, A. A., Samsuddin, S. F., \& Ali, Z. (2019). Mirror-mirror on the wall, what climate change adaptation strategies are practiced by the Asian's fishermen of all?. Journal of Cleaner Production, 232, 104-117. https://doi.org/10.1016/j.jclepro.2019.05.262

Sriraman, B. (2005). Are mathematical giftedness and mathematical creativity synonyms? A theoretical analysis of constructs. Journal of Secondary Gifted Education, 17(1), 20-36. https://doi.org/10.4219/jsge-2005-389

Stolte, M., García, T., Van Luit, J. E., Oranje, B., \& Kroesbergen, E. H. (2020). The contribution of executive functions in predicting mathematical creativity in typical elementary school classes: A twofold role for updating. Journal of Intelligence, 8(2), 26. https://doi.org/10.3390/jintelligence8020026

Tong, D. H., Loc, N. P., Uyen, B. P., \& Son, T. H. (2020). Enhancing Creative and Critical Thinking Skills of Students in Mathematics Classrooms: An Experimental Study of Teaching the Inequality in High Schools. Universal Journal of Educational Research,8(2), 477-489. https:// doi.org/10.13189/ujer.2020.080219

Tubb, A. L., Cropley, D. H., Marrone, R. L., Patston, T., \& Kaufman, J. C. (2020). The development of mathematical creativity across high school: Increasing, decreasing, or both?. Thinking Skills and Creativity, 35, 100634. https://doi.org/10.1016/j.tsc.2020.100634

UNESCO (2015). Education for all 2000-2015: Achievements and Challenges. EFA Global Monitoring Report 2015. Paris, France. Publication by the United Nations Educational Scientific and Cultural Organization. 499 pp. ISBN-978-92-3-10085-0.

Van Harpen, X. Y., \& Sriraman, B. (2013). Creativity and mathematical problem posing: an analysis of high school students' mathematical problem posing in China and the USA. Educational Studies in Mathematics, 82(2), 201-221. https://doi.org/10.1007/s10649-012-9419-5

Velikova, E., \& Petkova, M. (2019). Analysing Students' Creativity in Integrating GeoGebra Applets in Solving Geometrical Problems. Baltic Journal of Modern Computing, 7(3), 419-429. https://doi.org/10.22364/bjmc.2019.7.3.08

Wahyudi, D., Waluya, H. S., \& Isnaro, S. M. (2019). Schemata in Creative Thinking to Solve Mathematical Problems About Geometry. Universal Journal of Educational Research, 7(11), 2444-2448. https://doi.org/10.13189/ujer.2019.071122

Wood, D., Lindsay, N. J., Gluth, S., Corso, R., \& Bilsborow, C. (2017). Facilitating creative problem solving in the marketing curriculum in response to the demands of the networked information society. In The Customer is NOT Always Right? Marketing Orientationsin a Dynamic Business World (pp. 12-21). Springer.

Yaniawati, P., Kariadinata, R., Sari, N., Pramiarsih, E., \& Mariani, M. (2020). Integration of e-Learning for Mathematics on Resource-Based Learning: Increasing Mathematical Creative Thinking and Self-Confidence. International Journal of Emerging Technologies in Learning (iJET), 15(6), 6078. https://doi.org/10.3991/ijet.v15i06.11915 